臨㕅

\title{
中脳水道閉塞およびADH異常分泌症候群を 伴なつたsarcoidosisの1例
}

\begin{tabular}{|c|c|c|c|c|c|c|}
\hline \multicolumn{7}{|c|}{ 東京大学医学部吉利内科 } \\
\hline 吉利 & 和 & 鈴木 & 秀郎 & 内海 & & 胖 \\
\hline 鈴木 & 宏 & 清水 & 直容 & 蔡 & 瑞 & 熊 \\
\hline 相沢 & 力 & 荝家 & 利承 & 山中 & & \\
\hline 二瓶 & 宏 & 飯野 & 四郎 & & & \\
\hline
\end{tabular}

\section{A CASE OF SARCOIDOSIS ASSOCIATED WITH OCCLUSION OF AQUEDUCT OF MIDBRAIN AND INAPPROPRIATE SECRETION OF ADH SYNDROME,}

Yawara Yoshitoshi, Hidero Suzuki, Yutaka Utsumi,

Hiroshi Suzuki, Naokata SHimizu, Zuiyu SAI, Chikara Aizawa, Toshitsugu Kariya, Takeshi, Yamanaka, Hiroshi Nihei and Shiro IrNo

The First Department of Internal Medicine, Faculty of Medicine, University of Tokyo

概要 サルコイドーシスの経過中, 中脳水道閉塞に上ると思われる頭痛, 照心, 呕吐, めまい、難

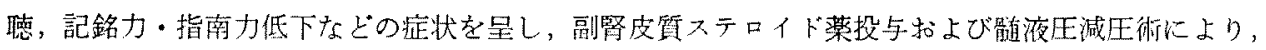
一時, 小康をえたが，再び，記銘力・指南力低下とともに, 低 $\mathrm{Na}$, 低Cl血症, 尿中 $\mathrm{Na}$, Cl排泄增加,

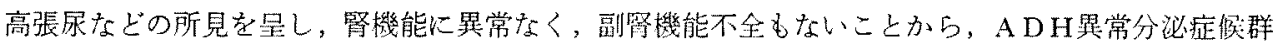
之考克ら机た症例を報告する，本例の脳圧六進症状，水電解質代謝異常は副腎皮質ステロイド薬が落 効を示したことから，いずれもサルコイドーシスによると考えた。

サルコイドーシスで神経症状を呈するものは 5 〜6\%にみられるが1)，末梢神経障害によるもの が主で，中枢神経障害によるものは1/3である。と くに，本例のよ5に，中脳水道閉塞を示した例 は，現在までの報告では8例にすぎず，本邦では 報告を見ない

また，A D H異常分泌症候群は，1957年，Schwartzら ${ }^{21}$ により, 初めて気管支癌の症例が報告

炤和 42 年 7 月 8 日 第186回関東地方会推点
されて以来, 各種の肺疾患, 脳疾患, その他で報 告されているが，サルコイドーシスによつて起こ つた例は，現在までのところ，報告されていな ᄂ.

われわれは中脳水直閉塞および A D H 異常分泌 症候群をあわせ伴なつたサルコイドーシスの非常 にまれな症例を経験したので報告する。

\section{症例}

H. N., 31才, 男, 工員。

主訴：しゃっ<り, 記銘力・指南力低下 
家族歴： 特記すべきことはない

既往歴：ツベルクリン反応は10才で陽転.

現病歴： 昭和38年春, 胸部 X線像で肺門陰影 増強を指摘され，PAS，INHを半年服用し た。この時, ッベルクリン反応は陽性であつた。 同年 7 月, 虹彩炎といわれた。

40年 4 月中旬, 後頭部痛, 悪心, めまい, 耳鳴 りが出現し、メーエール症候群として治療をう け, 一時, 軽快した。このころより書字能力が低 下した。 5 月10日, 発作的に悪心, 呕吐が起こ り，以後，この発作が頻発するようになり、左聴 力低下も出現した， 6 月になり，記銘力低下，歩 行時, 右へ偏ることに気づかれた。月ころより 左上腕三頭筋が腫脹し, 压痛を伴ない, 徐々に増 大した．9月に入り，うつ血乳頭を発見され，小 脳腫浧の疑いで，9月14日，当科へ第 1 回目の入 院をした。

入院時理学的所見：記銘力 指南力低下、難 聴, ロンベルグ現象陽性, 指指試験・指鼻試験拙 劣, 歩行時右偏行, 書字拙劣, 筋力低下

検查所見： 赤沈 $6 \mathrm{~mm} / \mathrm{hr}$, C R P ( - ), Wa-R (一),ツベルクリン反応 (一). Kveim反応 $(+)$. 血液生化学的検査; 総蛋白 $7.6 \mathrm{~g} / \mathrm{dl}, \mathrm{A} / \mathrm{G} 1.2$ $(\gamma$-gl $23 \%)$ ，尿素窒素 $12 \mathrm{mg} / \mathrm{dl}, \mathrm{Na} 132 \mathrm{mEq} / \mathrm{l}, \mathrm{K}$ $4.6 \mathrm{mEq} / l, \mathrm{Cl} 90 \mathrm{mEq} / l, \mathrm{Ca} 9.7 \mathrm{mg} / \mathrm{dl}, \mathrm{P} 3.8 \mathrm{mg} / \mathrm{dl}$, 総コレステロール $190 \mathrm{mg} / \mathrm{dl}$, GOT16単位, GP T 19 単位, B S P 45分值 $2.5 \%$. 腎機能娭査; P S P 15分值 30\%，2 時間值 $60 \%$ 。呼吸機能検 査; 正常範囲。髄液娭査; 初圧 $205,5 \mathrm{ml}$ 採 取, 終圧 $120 \mathrm{mmH}_{2} \mathrm{O}$, クエッケンステット圧上 昇, 細胞数 $59 / 3$, ヘンディ(H), 総蛋白 $87 \mathrm{mg} / \mathrm{dl}$, トリプトファン反応 $(+), \quad$ ('l $114 \mathrm{mEq} / \mathrm{l}$, 糖44 $\mathrm{mg} / \mathrm{dl}$ 。左上腕三頭筋生検像 ; 間質のリンパ球浸 潤, 類上皮細胞よりなる肉芽腫が見られるがサル コイドーシスとは決め壳ない

斜角リンパ節生検像（図 1); 類上皮細胞上り なる肉芽腫が散在し、サルコイドーシスの所見を 示している。X線㭘查 (図 2); 胸部一肺門陰影 増強, 肺野の網状ないし点状陰影増加, 頭蓋、骨一
指圧痕增強, 縫合軽度離開, 後床突起破壊. controlled pneumoencephalogram; 空気は第 4 脳 室には入るが中脳水道より上には入らず 脳室撮 影像（図 3 ）; 第 3 脳室拡大, 中脳水道上部に閉 塞. 腿科的検查; 両側のらつ血乳頭, マリオッ 卜盲点拡大を認めるも，サルコイドーシスを示す 所見なし。耳鼻科的検查；両側軽度難聴あり， 障害部位は上オリーブ核より上方と考光られた。

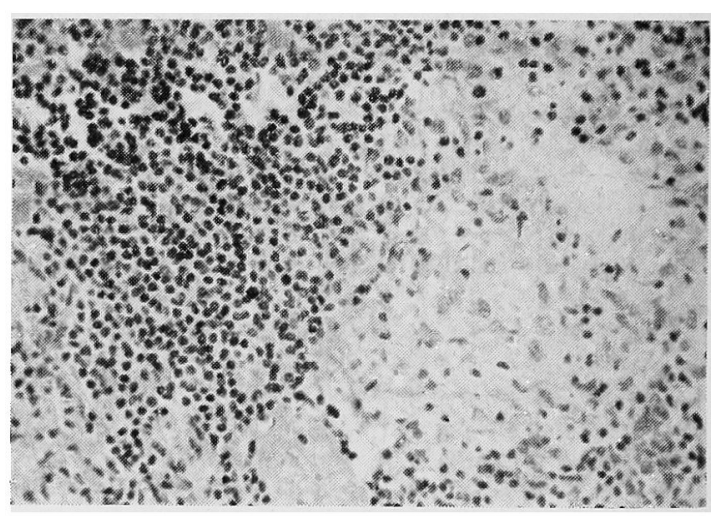

图 1. 斜角リンパ節生検像. 頪上皮細胞よりなる肉 䊒腫が見られる。

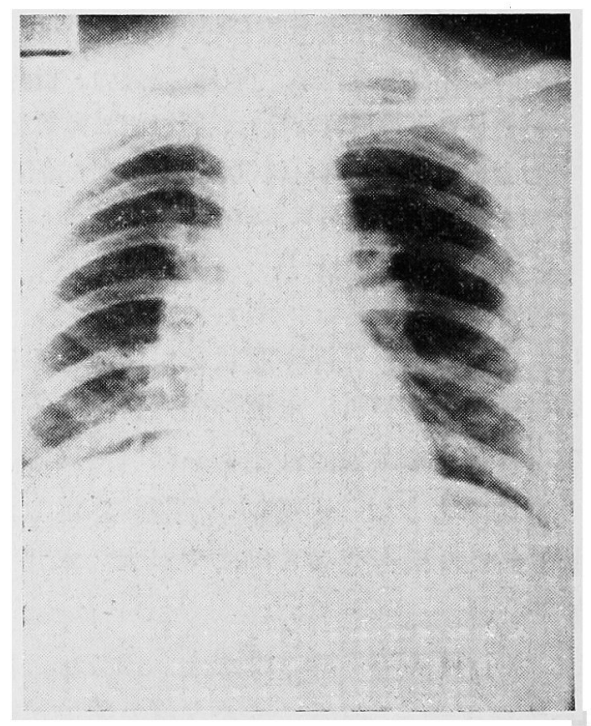

図 2. 初回人院時, 胸部 $\mathrm{X}$ 線像。肺門陰影がやや 增強し, 肺野に点状ないし網状陰影が增加 している. 


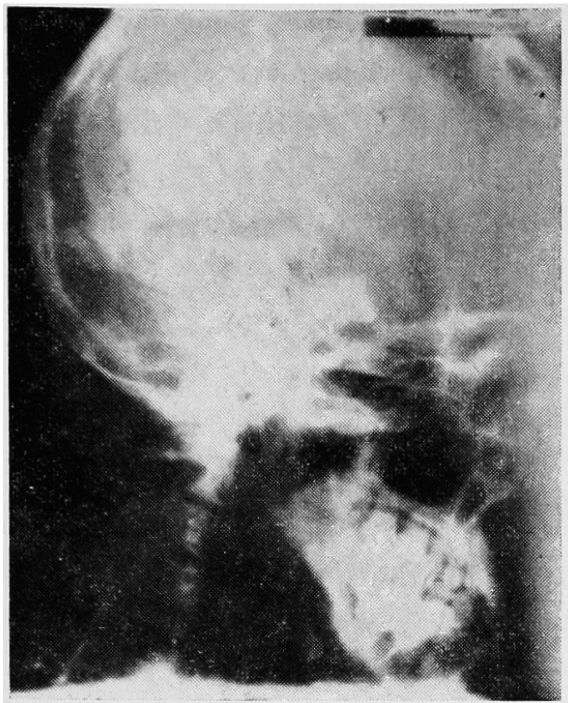

図 3. 脳室撮影像. 第 3 脑室の抾大と中脳水道上 部に閉塞がある。

入院後経過：9月 25 日か 5 prednisolone 30 $\mathrm{mg} /$ dayを泍減投与，10月31日で中止したが，投与 開始後から，各種症状は急速に改善した。

中脳水道閉塞があり, 将来, 䯣液圧がいつそう 上昇する可能性があつたので，41年 1 月11日東大 脳神経外科で, 後頭下開頭術を行なつた。手術所 見では，広範なくも膜炎および脳室上衣炎が見ら れたが，肉眼的にも，顕微鏡的にも肉芽腫の形成 はみら机なかつた。中脳水道はMagendi孔より 4 cmの深さのところに閉塞があることが確認され た、 Torkildsen手術を行なつた。

術後, 当科入第 2 回目の入院をしprednisolone および抗痉挛薬の投与をつつけ，自覚的にも，他 覚的にも異常所見は見られなかつた。1月下旬， 抗痉挛薬による肝障害を起こしたが，経過も良好 で3月中旬退院した．

昭和41年 9 月中旬，しゃっくりが頻発するよう になり，記銘力低下も気つかかるようになり10月 6 日，第 3 回目の入院をした。

入院時現症：しゃっ々り 記銘力 指南力低 下 その他には理学的に異常所見なし.

入院時検査：赤沈 $4 \mathrm{~mm} / \mathrm{hr}$. C R P (一). 尿
屎異常なし、末梢血液像；血色素 $102 \%, \mathrm{Ht}$ 值 $47 \%$, 赤血球数 $512 \times 10^{4}$ ，白血球数 5,000 ，血小 板 $21 \times 10^{4}$, 白血球百分率異常なし. 血液生化学的 検査； 総蛋白 $7.4 \mathrm{~g} / \mathrm{dl}, \mathrm{A} / \mathrm{G} 1.5$ ，尿素窒素 9 $\mathrm{mg} / \mathrm{dl}, \quad \mathrm{Na} 131 \mathrm{mEq} / l, \mathrm{~K} 5.1 \mathrm{mEq} / l, \mathrm{Cl} 92 \mathrm{mEq} / l$, $\mathrm{Ca} 9.2 \mathrm{mg} / \mathrm{dl}, \quad \mathrm{P} 3.8 \mathrm{mg} / \mathrm{dl}$, 総コレステロール 24.4 $\mathrm{mg} / \mathrm{dl}$, 尿酸 $4.4 \mathrm{mg} / \mathrm{dl}$, alk-P-ase 2.5Bessey単位, 黄疸指数 4 ,千モール混濁試験 2 単位, 硫酸亜鉛 試験 7 単位, GOT23単位, GP T 8 単位. 髄液 検查; 初压 195, $7 \mathrm{ml}$ 採取, 終圧 $125 \mathrm{mmH}_{2} \mathrm{O}$, キサントクロミー $( \pm)$, 細胞数 $71 / 3$ ， パンディ $(\mathrm{H})$, 総蛋白 $636 \mathrm{mg} / \mathrm{dl}$, トリプトファン反応 $(+)$, $\mathrm{Cl} 114 \mathrm{mEq} / \mathrm{l}$, 糖 $20 \mathrm{mg} / \mathrm{d}$, 線維素析出 $(+)$. 髄液 つ通過状態を見るため, 脳室に色素を注入, 腰椎 穿刺による色素出現時間を見たが，27分（正常上 限20分）で，遅延していた。

胸部および頭蓋骨のX線像は初回入院時とほぼ 同様の所見を示していた。

入院後経過: 入院後, 意識障害は次第に強く なり，自分の行動についての自覚がまつたくなく なり，10月15日には痉孪発作，引きつついて 1 時 間近く意識を言失した。それにともなつて，血液 生化学的検査では, 総蛋白が $7.4 \mathrm{~g} / \mathrm{dl}$ から $6.4 \mathrm{~g}$ /dlへ, Naが $131 \mathrm{mEq} /$ /から $123 \mathrm{mEq} / l へ, \quad \mathrm{Cl}$ が92 $\mathrm{mEq} / l$ から $85 \mathrm{mEq} / l, \mathrm{Ht}$ 值が $47 \%$ から $38 \%$ へとそ れぞれ減少した。

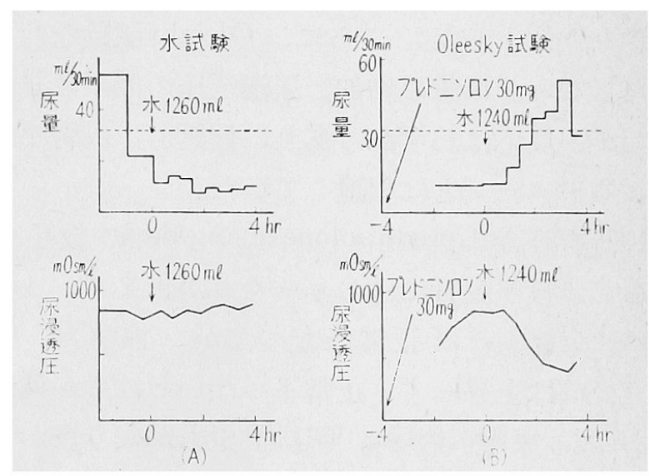

図 4. 水負荷試験（A）扰よびOleesky試験（B）. 尿量の図中の点線は試騃施行前 1 週間平均 の30分間尿县1. 説明は本交中にある。 


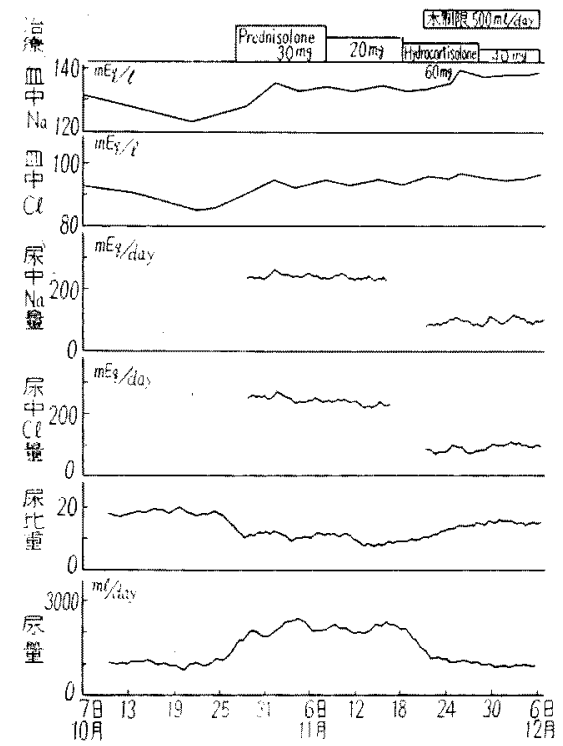

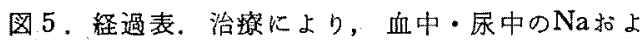
びClの著明な变化が見られた。

水負荷試験を行なつたところ，四4のように， 尿量の增加は見られず，逆に，試験施行前 1 週間 平均の30分間尿量 $33 \mathrm{ml}$ 上り，かなり減少し，矛盾 した反応を示した。康の㴡王でも，反応は見ら れず，ほとんど一定であつたが，血清澺圧は負 荷前 $278 \mathrm{mOsm} / l_{\text {s }} 258 \mathrm{mOsm} / l$ と低下し，その回 復はかなり和くれていた。この時の血中電解質は $\mathrm{Naが} 134 \mathrm{mEq} / l_{\text {が }} 127 \mathrm{mEq} / \mathrm{l}$ へ, Kが $5.0 \mathrm{mEq} / l$ から $4.7 \mathrm{mEq} / /$ ヘ, $\mathrm{Cl}$ が $111 \mathrm{mEq} / /$ $ら 99 \mathrm{mEq} / /$ へ とかなり低下した。ささらに，Oleesky試験を行な つたところ，尿量の増加，尿滲透王の減少は見ら れたが，反応はわずかであり，遅延し，副腎不全 によるパターンとは相違していた。

10月27日からprednisolone $30 \mathrm{mg} /$ dayの投与を 開始し，投与翌日にはしゃっくりが止まり，4 日 後には意識もほぼ正常となつたが，血中Na，CI は充分には上昇せず，正常下界ないしはや>低值 であり，尿中への $\mathrm{Na} 、 \mathrm{Cl}$ 排泄量もかなり多かつ た. 11 月21日からは水を $500 \mathrm{ml} /$ dayに制限し，血 中 $\mathrm{Na}, \mathrm{Cl}$ はや上昇し，尿中への $\mathrm{Na} 、 \mathrm{Cl}$ 排泄量 は著明に減少した（図５）。 その間に，prednisoloneを20mg/dayにし，さら に, hydrocortisone $60 \mathrm{mg} /$ dayk変え, $40 \mathrm{mg} /$ day, $20 \mathrm{mg} / \mathrm{day}$ と渐減し，12月12日に中止したが, 中止 により血中Na，Clはやや減少した。

12月16日，再度，水負荷試験を試みたところ， 水負荷後, 忢心, 叹吐があり，8時間後, 痉孪 発作ひさきつうき昏睡に陷つた。

棇量 600mgのprednisolone投与 および 高張食塩 水の点滴静注を行ない6日目に意識は正常となつ た。

その後, prednisolone, hydrocortisoneを使用し， 経過は良好で，血中Na，Clともに正常であつた． この間に，不充分ではあつたが，内分泌機能の検 查を行なつた，ACTH刺激試験では，尿中17-OH CSが $2 \sim 3 \mathrm{mg} /$ dayが $8 \sim 9 \mathrm{mg} /$ dayへと增加し 反応が見られた，尿中ゴナドトロピンは正常であ 门，甲状腺機能では，BMR-3\%，Triosorb30.8 \%であつた。

現在，水制限およびhydrocortisone $20 \mathrm{mg} /$ dayの 投与によつて, 臨床的にも, 検査所見上にも異常 はなく，外来通院を続けている。

\section{考案}

本症例は特有な胸部 $\mathrm{X}$ 線像, シベルクリン反応 陰性，Kveim反応陽性，典型的な斜角りンパ節生 検像からサルコイドーシスと䛦断された。

サルコイドーシスで, 臨床的に神経症状を呈し たものは，一般的には神経系にサルコイドーシス の病変があると考学られるが，サルコイドーシス に拈ける神経症状の出現頻度は報告により1〜29 \%とかなり差があるが，多くの報告を集計して， 平均の值をとると 5 〜 $6 \%$ となる。

神経系サルコイドーシスを中枢神経型と末梢神 経型に分けると，前者か $35 \%$ ，後者が65\%とな る。

中枢神経型では，頭蓋底の脳軟膜が侵されるこ とが多く，末梢神経型では，顔面神経麻瘰が多 w.

中枢神経型で本症例のように中脳水道閉塞を起 こした例は，1942年，Ericksonらにより初めて報 
告されて $\mathfrak{2}^{3}$ ，その後, Zemann, Goodson, Grinker, Jänick, Reymond, Degkwitz, Sherryの報告を加 总ると現在末で 8 例となる。 5 ち剖検例は 4 例 で, 剖検所見上して, 癒着性くも膜炎, 脑室上衣 炎が認められたるのがありこのよらな所見は， 本症例の開頭手術時の所見上一致し，本例の中脑 水道閉塞がサルコイドーシスによる可能性を強く 示唆するものである

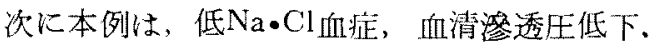
尿中Na・Cl排泄增加, 高張尿を呈し, 同時飞脱水 症状, 低血王などの体液喜失症状，篎機能障害学 よび副腎機能不全などの所見がなかつたことから AD H異常分泌症候群とい方る"

A D H 異常分泌症候群の病態は, 体液量の增加 とNa排泄増加による低Na血症であるが，本例で は，Ht值や血清Na值の変動がかなりあつたにも かかわらず，体重の变化はわずかであつた，

本例でのA D H買常分泌症候群は, 初回入院时 から低Na血症があつたこと，第 2 回目入院時に，

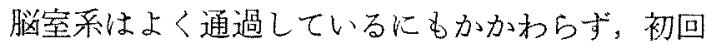
入院時之同様の精神症状があつたことなどから， すでに，初回入院時からあつたと考无られる

促来より，本邦で報告されている低 Na血泟の 例は，外国のそれにくらべ程度が軽く，低Na血症 による症状は強い本例でも血清Na值に比して, 痉挛や皆睡などの強い症状が見られた。本邦に拀 ける低Na血症 と臨床症状との関連性については 今後の検討に台たい:

本例では，第 2 回目の入院時，血清尿素窒素 が $9 \mathrm{mg} / \mathrm{dl}$ と低下していたことは，本症候群におい て，采球体滤過值が上昇するため尿素窒素が低下 するといわれている点より考光て興味深い

A D H 異常分泌症候群の治療としては，原疾慙 の治療が第一であるが，対症的には，水を500〜 $700 \mathrm{ml} /$ dayに 制限することが最も有効であり，副 腎皮質ホルモンでは， mineralocorticoidは有効で あるが，一般的には，glucocorticoidは無効であ るといわれている。また，救急の場合には高張食 塩水の点滴静注がよいとされている゙ 本症では，水制限だけでは不㳘分で，glucocorticoidの併用ではじめて有效であつた。

GlucocorticoidはADHの分澓や作用に対して 直接に作用したといらより，サルコイドーシスの 病变に対して效果があつたと考えられる.

アルコールはA DHの分泌を抑制するといわれ

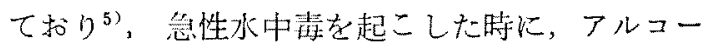
ルを投与したがとくに効果は見られなかつた。

また，水中輩時の疼挛に対しては，バルビタ 一ルは，効果がないといわれているが6)，本例で も，10月15日の痤孪発作以後，バビタールを含 む抗痉挛薬を使用していたにもかかわらず。12月 16 日の水負荷後, 㾏集起こした。

A D H異常分泌症候群 は，1957年Schwartz $5^{2)}$ が，気管支癌の 2 例に低 $\mathrm{Na}$ 血症扣よび尿中Na 排 泄增加龙認め，これが健康人に持続的にpitressin および水を投与した時の状態に類似していること に注目し，同症候群の名前を付けて報告したこと に始ま当。

しかし，1920年代から熱性疾患，とにに，肺炎 などで, 体液量の增加, 尿中八の電解質の垔失が 起こることは知られていた7)8

1950年, Simsら ${ }^{103}$ は肺結核で低Na血症を呈し た症例を発表し，Petersら”は中枢神経系の障害 によつて尿中へのNaおよびClの排泄が増加した 例を報告したが，その後，このような症例が“ce一 rebral salt wasting”として数多く報告された。

Schwartzの報告後, 種々の疾患でA D H異常分 泌症候群を示与ことがわかり，とくに，気管支癌 之䯣膜炎に合併することが多い

気管支癌では, “oat cell” carcinomaが多く， 摘出した腫瘍組織内にA D H様物質を多量に含え でいることが確認された例るある。

その注か，墨性腫瘍では，十二指腸癌，膵癌， 胸腺腫で報告されている。

また，各種の髄膜炎で本症候群が見られるが， とくに多いのは結核性髄膜炎である。

そのほか, 頭部外傷, 脳腫瘍, 脳膿瘍, 脳炎, くも膜下出血, Guillain-Barre症候群，急性ポル 
フィリン症, 精神分裂症, その他の中枢神経の障 害でも起こることが知られており，剖検で，下垂 体・視床下部にはまつたく異常が見られなかつた 例当古当。

さらに，脯炎，湖結核，肺アスペルギルス症な どの游疾忠や粘液水腫でも起こる。

またアアジソン病，下垂体前葉機能不全症，手 術後, 心不全, 旰硬变症などでも，ADHの分泌 異常がその病態に関係していると考光られてい る。

以上のべたようにADH買常分泌症候群は多く の疾患比見られるが，現在までサルコイドーシス 飞よる報告例はない

本例では，手術時，〔も膜炎，脳室上衣炎があ つたこと， prednisoloneが著効を示したことなど 加ら，A D H異常分泌症候群はサルコイドーシス により起こつたと考党られ，まし，サルコイドー シスによるものとすれば，本例はサルコイドーン スによるA D H暴常分泌症候群としては扎れおれ の知る限りでは世界で最初の例である。

\section{結語}

サルンイドーシスの経過中に中脳水道閉塞およ びA D H異常分泌症候群を伴なつた症例を報告し た。サルコイドーシスによる中脳水道閉塞例は本 例が 9 例目であり，A D H異常分泌症候群の報告 はまだ見られない、

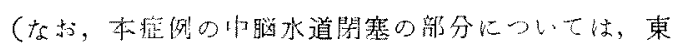
大脳神経外科加昭和 42 年 3 月発琵さ机ている。

\section{文献}

1) Silverstein, A., M.M. Feuer and L.E. Siltzbach: Neurologic sarcoidosis. Arch. Neurol., 12: 1-11, 1965. -2) Schwartz, W.B., W. Bennett, S. Curelop and F.C. Bartter. A syndrome of renal sodium loss and hyponatremia probably resulting from inappropriate secretion of antidiuretic hormone. Amer. J. med., 23 : 529-542, 1957. - 3) Erickson, T. C.. Boeck's disease (sarcoid) of the central nervous system. Report of a case with complete clinical and pathologic study. Arch. Neurol. Psychiat., 48 : 613-621, 1942. - 4) Bartter, F.C. and W.B. Schwartz: The syndrome of inappropriate secretion of antidiuretic hormone. Amer. J. med. , $42: 790-806$, 1967. -5) Strauss, M.B., J.D. Rosenbaum, and W.P. Nelson: The effect of alcohol on the renal excretion of water and electrolytes. J. clin. Invest., 29 : 1053-1058, 1950. -6) DeBodo, R.C. and K.F. Prescott: The antidiuretic action of barbiturates (phenobarbital, amytal, pentobarbital) and the mechanism involved in this action. J. Pharmacol. exp. Ther., $85: 222-233$, 1945. -7) Soule, H.C., T.E. Buckman, and D.C. Darrow: Blood volume in fever. J. clin. Invest., $5: 229-242,1928$, -8) Sunderman, F.W.: Studies of serum electrolytes. IV. The chloride and nitrogen balances, and weight changes in pneumonia. J. clin. Invest., $7: 313-332,1929$. -9) Peters, J.P., L.G. Welt, E.A.H. Sims, J. Orloff, and J.W. Needham: Salt wasting syndrome associated with cerebral disease. Trans. Ass. Amer. Physicians, 63:57-64,1950. -10) Sims, E.A.H., L.G. Welt, J. Orloff, and J.W. Needham: Asymptomatic hyponatremia in pulmonary tuberculosis. J. clin. Invest., $29: 1545-1557,1950$. 